\title{
Criminal Law Policy and Protection of Witnesses and Victims in Corruption Cases in Government Procurement of Goods and Services
}

\author{
Nandang Sutisna ${ }^{1}$, Rieneke Sara ${ }^{2}$ \\ Mahasiswa Program Doktor Ilmu Hukum Universitas Borobudur, Jakarta ${ }^{1}$ \\ Universitas Borobudur, Jakarta ${ }^{2}$ \\ \{nandangsutisna@outlook.co.id ${ }^{1}$, rineke_sara@borobudur.ac.id ${ }^{2}$ \}
}

\begin{abstract}
Corruption in the procurement of goods and services is part of a criminal law instrument. Criminal theory which aims to make the perpetrators or potential perpetrators afraid to commit crimes, because the modus operandi is quite diverse so it is difficult to detect. The Protection of Witnesses and Victims in cases of corruption in the procurement of goods and services of the government often receives terror from the perpetrators of misuse of goods and services reported by witnesses to law enforcement. It is necessary to protect witnesses and victims in the circle of cases of corruption in the procurement of government goods and services. The enforcement of criminal law on corruption in the procurement of government goods/services also needs to be promoted as a strengthening of the government in fighting corruption which hinders the absorption of the APBN/D (the State Revenue and Expenditure Budget) budget. Certainly, an appropriate criminal law policy is needed so that it will not only provide a deterrent effect to the perpetrators but also an awareness of the mistakes it can make. have an adverse effect on the life of the nation and state.
\end{abstract}

Keywords: Corruption; Procurement of Goods / Services; Criminal Law; Policy; Protection of Witnesses and Victims

\section{Introduction}

In 2019, Indonesia's Corruption Perception Index (CPI) is at a score of 40 with a ranking of 85 based on data from Transparency International Indonesia (TII). Meanwhile, Indonesia's 2020 Anti-Corruption Behavior Index (IPAK) was 3.84 on a scale of 0 to 5 , this figure is higher than the 2019 achievement of 3.7. These numbers certainly make Indonesia have to improve by targeting a score of 5.0 in 2021. This condition certainly raises several questions regarding the handling of corruption in Indonesia.

This paper is intended at examining the part of the eradication of criminal acts of corruption, especially in the realm of goods and services procurement, the weak enforcement of criminal and administrative laws in the process of procuring goods and services is an interesting side to study, considering that there are many legal aspects related to the procurement of goods and services. One of them is the aspect of criminal law which is certainly dominant in the criminal act of corruption in Indonesia. 
Procurement of goods and services is an effort on the part of the user to obtain or realize the goods and services he wants using certain methods and processes to reach an agreement on price, time, and other opportunities. In essence, the procurement of goods and services can be carried out well, if both parties, both users and providers of goods/services, use the philosophical aspects of the PBJ, uphold the ethics and norms of the procurement of goods/services in force, follow the principles, methods, and processes of the procurement. raw goods.

In various cases, of course, there are obstacles and irregularities, including in the process of procuring government goods and services. The state financial losses arising from deviations from the regulations on procurement of goods and services are of considerable value. From 2015 to 2017 alone there were around 460 cases of corruption in the procurement of goods and services that entered LKPP, but only 5 cases were processed as crimes of money laundering and ironically none of the reports on these cases were processed as criminal corporate crime.

To close the gaps in the occurrence of corruption in the procurement of goods and services, the government continues to innovate, starting from the transparency of procurement planning to the general procurement planning system. Closing the loophole in the occurrence of corruption in the procurement of goods and services is very necessary so that the state is no longer disadvantaged by fraud in goods and service procurement transactions. Improving the concept of corruption in the procurement of goods and services is very important to determine the right policy direction for perpetrators of corruption in the domain of goods and services procurement in the future.

The objectives to be achieved from this research are (1) to know the obstacles in the enforcement of the criminal law in the criminal act of corruption in the procurement of goods and services in Indonesia, and (2) to know the protection of witnesses and victims in cases of corruption in the procurement of government goods and services.

\section{Research Method}

In this study, researchers used a normative juridical approach which aims to find legal norms and norms in formulating criminal acts of corruption in the procurement of goods and services. the approach method used is in cases of corruption in the procurement of goods and services in Indonesia. Because this study conducted more literature review studies, the data sources used were files of PBJ corruption complaints from the public who entered LKPP and the KPK and a review of laws and regulations related to corruption in the procurement of government goods and services.

Data was collected by synchronizing data from the media with literature reviews on state laws related to corruption and government procurement of goods/services as well as related books. The research location is in the Goods and Services Procurement Policy Institute (LKPP). Because the data we need to see the policies on handling corruption are in the LKPP and the KPK.

\section{Analysis and Description}

\subsection{Electronic Procurement of Government Goods and Services}


Procurement of government goods and services is carried out electronically (eprocurement) to build a government procurement system for goods and services that is free from corrupt practices. This service for procuring goods and services in the domain of the Government Procurement Policy Institute (LKPP). This government procurement system for goods/services is made in an electronic system that makes it easier for goods/service providers to provide bids to the government. Electronic procurement itself means that the procurement of goods/services is carried out using information technology and electronic transactions under statutory provisions.

The implementation of information technology innovation policies in terms of government procurement of goods/services considers aspects of effectiveness and efficiency in a more economic context so that it does not require a lot of budget from the government. Of course, it requires a strategy in handling corruption prevention in real-time. Broadly speaking, eprocurement is divided into two types, namely electronic auctions (e-tendering) and electronic purchases of goods/services (e-purchasing). As regulated in Presidential Decree No. 54/2010, the implementation of e-procurement is manifested in two supporting organizations, namely the Electronic Procurement Service (LPSE) and the Procurement Service Unit (ULP).

\subsection{The Potential for Corruption in the Procurement of Government Goods and Services}

Procedures for drafting a general procurement plan and preparation for the implementation of government goods/services procurement that produces general procurement planning documents and goods/services procurement documents. As in Presidential Decree No. 54 of 2010 in Chapter III Article 8 paragraph (1) states that budget users (PA) have the duty and authority to determine the general procurement plan and publicly announce the general procurement plan at least on the K/L/D/I website, as well as article 17 paragraph 2 that the ULP/procurement officials prepare a plan for the selection of providers of goods or services and establish procurement documents.

Several gaps in the potential for corruption in the procurement of government goods/services consist of: (1) bribery and embezzlement, (2) forgery and extortion, (3) misuse of position/authority, (4) conflicts of interest / or officials who use budget and implementers of PBJ have self-employment, (5) favoritism (favoritism), and (6) commissions, nepotism, illegal contributions/contributions. The stages of the procurement of goods/services and forms of potential deviation, the authors summarize in each stage of the procurement, here are the potentials:

Procurement Planning, at this stage of procurement the potential deviations are:

a. Making up procurement (project orders, without evaluation, requirements from the previous budgeting process related to the budgeting system).

b. Inflation of the budget (costs, volume, materials, and quality associated with the budgeting system).

c. Unrealistic schedule of procurement (partners who know in advance who can be ready to participate in tenders)

d. Procurement that leads to certain products/specs (closing opportunities for other companies/entrepreneurs, leading to PL / directed procurement plans/packaging engineering for KKN.

The formation of the Tender Committee, at this stage the gaps in the occurrence of irregularities are in:

1. Transparency problems (the committee cannot guarantee equality in obtaining information for all tender participants). 
2. The committee does not act fairly and professionally in all stages of procurement / the committee is impartial/dependent.

3. Integrity problems (have been involved in $\mathrm{KKN}$ cases, have backgrounds that encourage closeness with partners).

Company prequalification, at this stage the potential for irregularities occurs in:

a. The qualification process is not carried out/only done once for several procurement projects.

b. Passing companies that do not meet administrative and technical requirements (company class, capital adequacy, and job scope).

c. Passing the company meets the requirements but has a defect in the performance of the project.

d. Passing more than one company owned by one entrepreneur (many companies but the owner and address of the same person).

e. Passing partners who use fake documents/do not get legalization from the relevant agencies (the committee does not check the report).

To prepare tender documents, the potentials that may occur at this stage are:

1. Engineering evaluation criteria.

2. Non-standard tender documents.

3. Specifications refer to certain goods/services (scope of work and specifications of goods, followed by evaluation criteria which are also irrational/close the possibility for all partners to fulfill them, for example recommendations from main distributors abroad that may only be given to one company in Indonesia. country).

4. Incomplete documents can provide opportunities for corruption (scope of work, quality, total size/volume, etc.).

Announcement of auctions, the potential deviations are:

a. The announcement period is too short (judging from the reasonable time needed to meet the auction prerequisites).

b. Announced in an unknown media (not by the existing regulations).

c. The contents of the auction announcement are incomplete.

Retrieval of auction documents. There is a difference in the tender document information provided to each tender participant (this has been reported by one of the KPU ballot box tender participants).

Determination of Self Estimated Price (HPS), the potential for fraud at this stage is:

1. Budget inflation, in this case, the HPS is engineered in terms of both the number of work units or the volume, the bids from partners are brought closer to the inflated price.

2. Include elements of workers whose work processes have been completed (from other budgets/project sources).

3. Non-standard base price (taking the highest qualification).

4. Involvement of potential winners in determining HPS.

Explanation of the auction, at this stage the potential for corruption to occur in terms of:

a. Limited Pre-bidding meeting is conducted.

b. Associates do not receive complete and open information (complete information is carried out outside the explanation forum) resulting in inequality of information and may affect the offer.

Evaluation of bids, at this stage there are gaps in corruption in:

1. Closed and hidden evaluation.

2. The auction participants are patterned in the context of collusion. 
3. There is no field checking (confirmation) for technical requirements (company accreditation) and administrative (completeness of administrative prerequisites) or defect evaluation criteria.

4. There is no confirmation of the terms of the bid guarantee.

The announcement of the winning candidate, at this stage the potential for cheating is on: (1) Announcements are very limited; (2) The date of the announcement was deliberately postponed; (3) Non-informative announcements.

Rebuttal from auction participants, the potential for fraud that often occurs at this stage is: (1) The auction committee did not respond to all objections; (2) The substance of the objection that is not responded to; (3) Performance rebuttals to avoid accusations of tenders are regulated.

The appointment of the auction winner, at this stage, has the potential for corruption in terms of: (1) Postponement of appointment letter (must be obtained by bribing); (2) The appointment is expedited before the objection period ends. Signing of contracts, the contract is postponed because it has to be obtained by way of bribes.

For the provision of goods/services to users, the potential for fraud that often occurs at this stage is:

a. The criteria for receiving ordinary goods or not according to the specifications stated in the contract document.

b. The volume of goods that is not the same as what is written in the auction documents.

c. After-sales guarantees that are deliberately falsified.

d. Not according to technical specifications and qualifications.

e. The existence of a contract change in the middle of work orders to allow changes in specifications of goods and job qualifications.

\subsection{Regulations on the Formulation of Corruption in the Procurement of Goods and Services}

The policy on the corruption of procurement of goods and services is regulated in the articles of the Criminal Code, namely regarding: Feeding; Cheating; Department crime; Extraction; National land-use; and Participate in wholesalers

Regarding corruption, it is also regulated in Law Number 31 of 1999, which formulates several changes in criminal threats for perpetrators of criminal acts of corruption. The law recognizes the death penalty as stated in Article 2 paragraph (2) which reads: "If the criminal act of corruption as referred to in paragraph (1) is committed under certain circumstances, the death penalty may be imposed". The definition of "certain circumstances" in this provision is intended as a deterrent to the perpetrator of a criminal act of corruption if the crime is committed when the state is in a state of danger by the applicable law, at the time of a national natural disaster, as a repetition of the criminal act of corruption, or at when the country is in a state of economic and monetary crisis.

In terms of regulations related to corruption, Law Number 31 of 1999 is the toughest and most severe law in ASEAN although in practice, this explanation is declared invalid because Law Number 20 of 2001 concerning amendments to Law Number 31 of 1999 concerning the Eradication of Corruption has been formulated and there is an explanation in that article. Changes to the criminal sanction other than the death penalty are the minimum criminal threats related to custody and fines. The concept of the minimum criminal penalty is a new concept that is not recognized in the Criminal Code. 
There are many shortcomings in the formulation of threats in the minimum punishment, including not formulating criminal guidelines to implement this minimum criminal threat. The special laws outside the KUHP should have made separate rules on their implementation because they are a logical consequence of Article 103 of the Criminal Code.

With this minimum punishment guideline, it cannot be determined whether the minimum punishment can be commuted or can be aggravated. Another anomaly that appears in the minimal criminal pattern. There are offenses punishable by a maximum sentence of 20 years imprisonment and a minimum sentence of 4 years imprisonment as stated in Article 2 and Article 12. Meanwhile, offenses punishable by a maximum sentence of 20 years imprisonment. But even so, the minimum penalty is 1-year imprisonment in article 3 . In other offenses, a minimum sentence of 1 year is punishable with a maximum of 5 years in prison as in Article 9 and Article 11.

With the existence of the concept of a cumulative formulation system and an alternative cumulative formulation system in the criminal threat of this law which is used is not clear because the concept raises the most basic simple question, namely why the corruption offense in the form of enriching oneself in article 2 is punishable by cumulative punishment while abusing authority in Article 3 is punishable by alternative cumulative punishment. Even though these two offenses have the same maximum penalty and the weight/quality of the offense is the same.

Thus it can be concluded that the form of the law can be said to be inaccurate in formulating criminal sanctions in criminal acts of corruption so it is natural that in this reform era, corruption is still rampant. The uncontrolled development of criminality, which is increasing, can be caused by the incorrect types of sanctions chosen and stipulated. At least the inaccurate formulation of crimes in the law can be a factor in the emergence and development of crime.

The regulation of sanctions related to corruption in the procurement of government goods and services is contained in Presidential Regulation Number 16 of 2018, found in Article 78 paragraph (4) namely:

a. Sanctions were dropped in elections.

b. Disbursement of guarantees sanctions.

c. Blacklist Sanctions.

d. Sanctions for damages, and/or

e. Penalty fine.

Based on the formulation of sanctions from the Presidential Decree, it seems that the formulator adheres to a consequentialist theory, in which punishment is a result of behavior that causes harm, and it is appropriate for the perpetrator to receive criminal sanctions as a result of losses to the state. In this case, it is hoped that in the future crimes can be prevented because the main objective is punishment. With the formulation of these sanctions, criminal reporting becomes the goal so that the legislators view that crime can bring good because it can prevent worse incidents and think that there is no other equal alternative in overcoming this deviation.

Policies and strategies for eradicating corruption in the procurement of government goods/services can be carried out through a systemic approach, namely by improving the existing system in the procurement of government goods/services itself. Some that can be done are as follows:

a. Structure, In terms of structure, it is necessary to improve all the institutions/organizations that administer the judiciary to minimize the occurrence of corruption. 
b. Substance. Substantially, reforms of various normative regulations and provisions need to be carried out, the pattern and will of community behavior in the legal system also need to be changed in its mindset so that in substance the handling of corruption can be carried out comprehensively.

c. Legal culture. The low level of legal awareness of the Indonesian people, which is still low, needs improvement efforts from judicial administrators and law enforcers to increase public confidence in legal instruments in this country.

d. Political will. If we discuss political will in policies and strategies for handling corruption, we need to discuss related to the law enforcement officer act, policymakers need to make instruments to improve the image of law enforcement officers. Another policy strategy is to implement preventive measures against criminal acts of corruption by $\mathrm{PBJ}$, early detection of corruption crimes, and repressive measures when there is a criminal act of corruption.

\subsection{Criminal Law Policy for Witness and Victim Protection in Indonesia}

The criminal law policy formulated in the context of preventing future corruption crimes has been pursued in the Corruption Eradication Law (Law No.10 of 2015). The concept of the Corruption Eradication Law, basically almost all provisions of corruption and other crimes related to corruption in the Corruption Eradication Law.

Based on the principle of equality before the law (equity before the law) which is one of the characteristics of a rule of law, witnesses and victims in a criminal justice process must be guaranteed legal protection. Protection of witnesses and victims must refer to the five principles namely: 1) respect for human dignity; 2) a sense of security; 3) justice; 4) not discriminatory; and 5) legal certainty to provide a sense of security for witnesses and victims in giving information to every criminal justice process. For the sake of legal protection and security for everyone who knows or finds something that can help a criminal act that has reported it to law enforcement, it is necessary to create a climate that is conducive to creating public participation in exposing criminal acts. This protection is intended so that the community does not feel threatened or intimidated in terms of both their rights and their lives.

At present, many criminal cases have not been touched by the legal process for trial because neither witnesses nor victims dared to disclose them, while other evidence obtained by investigators is very inadequate. Threats of mistreatment, kidnapping of victims, witnesses, or their family members to murder are the main reasons that make them feel discouraged to be involved in giving testimony.

In cases of criminal acts of corruption, the government must make policies related to the protection of witnesses and victims. The Law on the Protection of Witnesses and Victims is based on MPR Decree No. VIII of 2001 concerning the recommendation of the Policy Direction for the Eradication and Prevention of Corruption, Collusion, and Nepotism, that it is necessary to have a law regulating witness protection. This matter needs to be considered in the formation of the Law on Protection of witnesses and victims, namely in the juridical definition of witnesses and victims to find the boundaries of the regulation. In positive law in Indonesia, the problems of witnesses and victims have been regulated even though they are simple and partial in nature. This can be seen in both material criminal law and formal criminal law.

In the material criminal law contained in the Criminal Code (KUHP) Article 14 letter c, concerning the judge who will impose conditional criminal law, it is determined that there are general conditions and special conditions that must be met by the convict during his probation 
period. in the form of a crime within a certain time, which is shorter than the probation period, must compensate all or part of the losses incurred by the maker. In formal criminal law as stated in KUHAP Article 1 point 26 which includes the meaning of a witness is a person who provides information for the investigation, prosecution, and trial regarding a criminal case which he has heard himself has seen for himself and experienced himself.

Since the promulgation of Law Number 13 of 2006 concerning Protection of Witnesses and Victims (UU PSK) which aims to protect witnesses and victims at all stages of the judicial process, protection is intended as all efforts to fulfill rights and provide assistance to provide a sense of security to witnesses and/or victim. If it is based on experience, the current implementation is considered to be not by the times, and obstacles are often found in its implementation, for example, protection of whistleblowers or reporters and perpetrator witnesses who are willing to cooperate (Justice collaborator), whose current regulation is still minimal in the PSK Law, then coupled with the institutional formulation and authority that are deemed to be still minimal as well as various sectoral regulations that have the potential to overlap with regulations and authorities, thus potentially hindering witness protection and the fulfillment of victims' rights.

In 2014, the government established Law Number 31 of 2014 concerning amendments to Law Number 13 of 2006 concerning Protection of Witnesses and Victims. In the preamble (weighing) section of the new PSK Law, several provisions were found that adjust to the development of the legal needs of the community. Several new things have been regulated both in terms of protection of witnesses, victims, and perpetrator witnesses as well as from the aspect of enforcers, namely in this case the Witness and Victim Protection Agency (LPSK).

The new PSK Law contains details regarding the protection of witnesses and victims. In this law, it is stated that witnesses and victims who are related to the interests of investigations, investigations, prosecutions, and examinations in court hearings have several rights. Apart from witnesses and/or victims, the rights granted in certain cases can be given to perpetrator witnesses, reporters, and experts, including people who can provide information relating to a criminal case even though they have not heard it themselves, they have not seen it themselves and they have not experienced it themselves. as long as the person's statement is related to a criminal act.

\subsection{Criminal Law Enforcement on Corruption in the Procurement of Goods and Services}

Procurement of goods/services must be carried out transparently, and not in favor of one of the partners and there is no conspiracy between the PA / KPA / Committee / ULP / Procurement Officials with one of the partners or between partners and other partners, to obtain efficient prices and goods/appropriate services as desired. The prohibition is contained in Presidential Regulation No. 54/2010 concerning Government Procurement of Goods / Services Article 24 paragraph (3) point d. stated:

"In the packaging of goods / services, the PA (Budget User) is prohibited, determining the criteria, or procurement procedures that are discriminatory and / or with non-objective considerations".

Criminal sanctions (penalties) are a central part of criminal law. Various types of crimes have been regulated in Article 10, which consists of (1) Principal Crime and (2) Additional Criminal. The main crime itself includes capital punishment, imprisonment, imprisonment, and fines. Additional criminal provisions consist of revocation of certain rights, confiscation of certain items, and the announcement of a judge's decision. 
Concerning the imposition of criminal sanctions (penalties) Jan Remmelink stated that serious criminal sanctions will be imposed if other lighter law enforcement mechanisms are no longer useful. Based on this statement, criminal sanctions are the last resort (ultimatum remedium) after other legal sanctions have been determined. Concerning the severity of sentences in the Criminal Code, there are 4 (four) systems of punishment:

a. Absortion System (Absorption System).

b. Aggravated Absortion System (Verscherpte Absorption Stelsel)

c. A lightened cumulation system (gematigde cumulatie stelsel)

d. Cumulation System (cumulatie stelsel).

In the Criminal Code the absorption system (absprtie stelsel) is regulated in Article 63 which stipulates:

1. If an act falls under more than one criminal rule, only one of those rules is imposed; if different, the one imposed which contains the heaviest principal penalty.

2. If an act falls under a general criminal rule, it is also regulated in a special criminal rule, then only the specific one is applied.

Observing the provisions of Article 65 paragraph (1), it can be concluded that in the case of convictions several crimes which are punishable by similar basic crimes, only due to one crime. So Article 65 paragraph (1) is an absorption. The provisions of Article 65 paragraph (2) stipulate that the sentence imposed must not be more than the maximum legal maximum plus one-third. So that article 65 paragraph is an aggravated absorption system.

The cumulation system in the Criminal Code can be mitigated (gemetigde cumulatie stelsel) as regulated in Article 66 paragraph (1), namely in the case of concurrent actions, each of which must be viewed as an independent act so that it is called a number of crimes, which are punishable by the basic criminal that is not similar, then each of it is imposed, but the amount may not exceed the maximum sentence plus one-third of the heaviest sentence.

As in the Criminal Code, the cumulative system (cumulatie stelsel) is regulated in article 70 which stipulates: (1) if there is a coincidence as in the case in Article 65 and Article 66, both the violation is the coincidence with the crime, and the violation with the violation, then for each violation it shall be imposed criminal individually without deduction. (2) regarding violations, the maximum length of imprisonment and substitute confinement is one year and four months, while the maximum length of substitute confinement is eight months.

As with the criminal system, criminal law is also known as a theory of the purpose of punishment, namely: (1) absolute theory (retaliation theory); (2) relative theory (theory of prevention); and (3) combined theory.

The Corruption Eradication Commission (KPK) being a special institution that has the authority to eradicate corruption, apparently it has not been able to stop the rate of corruption in Indonesia. The problem is because its eradication only puts forward the criminal aspect, namely punishment. If we look at the theory only at the limitation of the deterrent effect, indeed, harsh penalties can slow down the rate of corruption, but cannot stop acts of corruption. Of course we need to prioritize and rely on the pattern of eradicating corruption with criminal law alone, making officials reluctant to become officials in the procurement of goods and services either as PPK or Procurement Service Unit (ULP) / Procurement Committee. So that has implications for the absorption of the APBN / APBD as the news is mostly published in the national media.

Based on the Bappenas report also shows the same thing that the expenditure budget of Ministries and State Institutions (K/L) in the 2020 APBN-P has absorbed $34.06 \%$. The slowness in the absorption of the APBN budget is indeed a crucial problem every year which hinders various programs. At least there are several things that cause it. First, the weakness of 
budget planning that reflects the weak and immature planning of government programs and projects. The second is the length of the budget discussion process, the Covid-19 pandemic has made the 2020 State Budget allocated for handling the pandemic. The government's move to refocus the budget, reallocation of expenditure reserves, and save spending on ministries/agencies. Third is excessive bureaucratic prudence, the need for flexible and overlapping regulations in the use of budgets so that it does not take up time in the administrative process. Next is the issue of procurement of goods/services (tenders), expenditure realization often increases in the third and fourth quarters of course this requires extra fast and precise work, especially since Indonesia is being affected by the Covid-19 pandemic which makes the problem of procurement of goods / services spending will have a significant effect on budget absorption.

Handling cases of irregularities in the procurement of goods and services should be initiated by identifying and clarifying these deviations in the realm of administrative law, civil law or criminal law. This identification and classification is necessary to determine which legal rules will be applied to in-concreto cases.

Corruption has the same characteristics as other conventional crimes, but corruption is often labeled as a white collar crime because the crime is dynamic in its modus operandi from all sides so that it can be said to be an invisible crime that is difficult to detect. Therefore, the pattern of eradicating corruption is not only carried out by punishing severely or the death penalty, but the application of other legal instruments such as enforcement of administrative law, for example.

\section{Conclusion and Suggestion}

\subsection{Conclussions}

Regarding the regulation of corruption in the procurement of government goods and services in the Criminal Code, it is also formulated in the Corruption Crime Law, but there are still weaknesses contained in this Corruption Law, one of which is the formulation of minimum criminal threats, namely not formulating criminal guidelines for implementing threats. this minimum criminal. The special law outside the KUHP should have made separate rules for its implementation, because this is a logical consequence of Article 103 of the Criminal Code. Formulation of corruption with the scope as defined in the Criminal Code Concept of 2012 was enough to provide deterrence or prevention against corruption, especially for White Collar Crime involving state officials, including law enforcement in the future.

The fulfillment of the right to security for witnesses and victims, especially in cases of corruption procurement of goods and services becomes an important requirement that the legal process in court is going well. Witnesses are those who have their own knowledge based on what they have experienced, seen, and / or heard regarding the alleged corruption in the procurement of government goods and services. Law Number 31 of 2014 concerning Witness and Victim Protection mandates the institutional strengthening of the LPSK in carrying out its duties of protection and fulfillment of rights, especially in cases of corruption and money laundering.

\subsection{Suggestion}


Some suggestions that the author would like to convey that the development of corruption in the procurement of government goods and services is not only in the position of criminal prosecution, but at the beginning there is a need for strengthening in the field of preventing the occurrence of criminal acts of corruption. When an online auction occurs, of course everything must be in a system that the procurement of government goods and services must be free from the practice of rasuah.

The policy strategy for handling corruption crimes needs to be carried out comprehensively between the two parties involved in the procurement of government goods/services, namely the buyer or user and the seller or provider of goods/services to be equally committed to the applicable law in Indonesia and commitment to the corruption and penalties in Indonesia. The next strategy is to improve the mentality of government goods and service providers so that they do not become corrupt or seek loopholes to act unfairly in the procurement of goods/services.

\section{Acknowledgement}

The author would like to thank for the promotor, Dr. Rineke Sara, MH who has given support and encouragement to write this scientific paper in the form of scientific journal and dissertation, this is a new experience for the author. I would like to thank the authors for my colleagues in the Doctoral of Law Program at the University of Borobudur Jakarta for their solidarity who work hand in hand to provide a spirit of togetherness to be able to graduate together.

\section{References}

[1] Amirudin. "Pemberantasan Korupsi Dalam Pengadaan Baran Dan Jasa Melalui Instrumen Hukum Pidana Dan Administrasi.” Jurnal Media Hukum 19, no. 1 (2012): $125-165$.

[2] Arifin, Zaenal. "Tindak Pidana Korupsi Dalam Proses Pengadaan Barang Dan Jasa Pemerintah.” Jurnal Hukum Responsif FH UNPAB 5, no. 5 (2017): 54-63.

[3] Artantri, Luh Putu Resti Mega, Lilik Handajani, and Endar Pituringsih. "Peran EProcurement Terhadap Pencegahan Fraud Pada Pengadaan Barang/Jasa Pemerintah Daerah Di Pulau Lombok." NeO Bis 10, no. 1 (2016): 16-32.

[4] Bappenas. Perkembangan Ekonomi Indonesia Dan Dunia Triwulan II 2020. Vol. 4, 2020.

[5] Haya, Hutomo Zulfikar Y. "Tinjauan Kriminologis Terhadap Kejahatan Korupsi Pengadaan Barang Dan Jasa Bagi Kepentingan Pemerintah" (2014): 1-76.

[6] Muhyiddin. "Covid-19, New Normal, Dan Perencanaan Pembangunan Di Indonesia." Jurnal Perencanaan Pembangunan: The Indonesian Journal of Development Planning 4, no. 2 (2020): 240-252.

[7] Sosiawan, Ulang Mangun. "Kontruksi Pra Peradilan Melalui Rekonstruksi Hakim Komisaris Sebagai Perlindungan Hak Tersangka Dalam Sistem Peradilan Indonesia." Jurnal Penelitian Hukum De Jure 18, no. 1 (2018): 73-92.

[8] Supriyanto, Eko Eddya. "Kebijakan Inovasi Teknologi Informasi (IT) Melalui Program Elektronik Government Dalam Meningkatkan Kualitas Pelayanan Publik Di Indonesia.” Jurnal Ilmu Pemerintahan: Kajian Ilmu Pemerintahan dan Politik Daerah 
1, no. elektronic government (2016): 141-161.

[9] Suyatmiko, Wawan, and Sekar Ratnaningtyas. Indeks Persepsi Korupsi Indonesia 2019, 2019. http://riset.ti.or.id/wp-content/uploads/2018/09/IPK-2017_Report1.pdf.

[10] Syayuti. "Implementasi Good Governance Pengadaan Barang Dan Jasa Pada Pemerintah Kabupaten Bungo (Studi Kasus Pada Dinas Pendidikan)," 2016.

[11] Transparancy International. Buku Panduan: Mencegah Korupsi Dalam Pengadaan Barang Dan Jasa Publik, 2006. https://www.mendeley.com/catalogue/96418a60-f81f3326-9338-d328aa8a0848/.

[12] Zaini, Zulfi Diane. "Implementasi Pendekatan Yuridis Normatif Dan Pendekatan Normatif Sosiologis Dalam Penelitian Ilmu Hukum.” Pranata Hukum, 2011.

[13] Peraturan Presiden Nomor 16 Tahun 2018 Tentang Pengadaan Barang/Jasa Pemerintah, 2018. http://kiss.kstudy.com/search/detail_page.asp?key=3424155\%0Ahttps://doi.org/10.101 6/j.rcim.2018.05.010\%0Ahttps://doi.org/10.1016/j.cie.2018.07.041.

[14] Peraturan Presiden Nomor 54 Tahun 2010 Tentang Pengadaan Barang/Jasa Pemerintah. Sekretariat Kabinet, 2010.

[15] PP No. 54 Tahun 2018 Tentang Strategi Nasional Pencegahan Korupsi, n.d. 
